\title{
Experimental study on fibre reinforced sandy soils behaviour under static loadings - drained and undrained conditions
}

\author{
Jorge Hernán Flórez-Gálvez ${ }^{1, *}$, Lucas Festugato $^{2}$, and Nilo Cesar Consoli ${ }^{2}$ \\ ${ }^{1}$ University of Quindío, Faculty of Engineering, Armenia, Colombia \\ ${ }^{2}$ Federal University of Rio Grande do Sul, Department of Civil Engineering, Porto Alegre, Brazil
}

\begin{abstract}
The effect of the addition of $0.5 \%$ of randomly distributed polypropylene fibres in a round grained sand, composed mainly of silica, is presented on laboratory scale. The samples were compacted with two void ratios $(0.75$ and 0.63$)$, corresponding to values of relative density of $50 \%$ and $90 \%$ respectively. 24 monotonic triaxial tests were performed, with initial effective mean pressures of 20,100 and $200 \mathrm{kPa}$. Half of samples were tested in drained conditions, and the other half in undrained conditions. For the samples subjected to drained conditions, the effect of the fibres was identified at the post-failure stage, by showing sustained increase of strength. The positive effect of fibres could also be observed through the increase of material friction angle. In the samples subjected to undrained tests, the addition of fibres reduced the contractive behaviour, mainly for those more compacted.
\end{abstract}

\section{Introduction}

Soil reinforcing technique with randomly distributed fibres has been consolidated as an innovative solution for several engineering problems.

Numerous studies have shown how fibres addition improves the mechanical behaviour of sands. One of the most important contributions is the increase of strength, observed mostly at post-peak conditions. Such effects have been evaluated in several studies, either with natural [1], [2] or synthetic fibres [3-12]. The use of natural fibres is commonly questioned because of their durability, and physical and mechanical heterogeneity [14].

For the stress-strain behaviour, it was found that fibres promote dilating response [3], decreasing thereby the tendency of pore pressure generation.

This work presents experimental results of polypropylene fibres reinforced quartzitic sand, subjected to drained and undrained triaxial tests, with three different levels of confining pressure, considering two relative densities (50\% and 90\%).

\section{Experimental programme}

Triaxial tests were conducted on fully saturated sand specimens, by applying effective confining pressures from 20 to $200 \mathrm{kPa}$. Two different relative densities were considered (50\% and 90\%). The specimens were compacted with no fibres and with $0.5 \%$ of fibres by dry weight of sand. The same number of drained as undrained triaxial tests were conducted, totalling 24 tests.

\subsection{Materials}

Uniform quarzitic sand (Osorio sand) from southern Brazil was used in this experimental programme. The Osorio sand was samples from the region of Osorio, near Porto Alegre (Fig 1). The soil is classified as non-plastic uniform fine sand (SP) with a specific gravity of solid of 2.62. The grain size distribution is entirely fine sand $(0.075 \mathrm{~mm}-0.42 \mathrm{~mm})$, with an effective diameter of 0.11 $\mathrm{mm}$, mean diameter of $0.20 \mathrm{~mm}$, and uniformity and curvature coefficient of 2.0 and 1.1, respectively. Mineralogical analysis indicated that the sand particles are predominantly quartz. The minimum and maximum void ratios are 0.6 and 0.9 , respectively [13].

Monofilament polypropylene fibres were used to soil reinforcing (Fig 2). The dimensions were: length $50 \mathrm{~mm}$, and diameter $0.1 \mathrm{~mm}$. The fibres have a specific gravity of 0.91 , tensile strength of $120 \mathrm{MPa}$, elastic modulus of 3 $\mathrm{GPa}$, and linear strain at failure of $80 \%$. The fibre content used was maintained constant in $0.5 \%$ by dry weight of soil.

\subsection{Sample preparation}

The compacted sand and fibre-reinforced specimens were prepared by hand-mixing following this order: dry soil, water and polypropylene fibres (when used). The specimens compaction technique was moist tamping in all cases. Undercompaction technique [15] was used in order to achieve more consistent results.

The specimens were statically compacted in three layers into a split mould $100 \mathrm{~mm}$ in diameter by $200 \mathrm{~mm}$ high, to a moisture content of $10 \%$ and void ratio of 0.75 and 0.63 , respectively consistent to a relative density of $50 \%$ and $90 \%$. The tolerances in dimensions of the prepared specimens ware: $\pm 1.0 \mathrm{~mm}$ diameter, $\pm 2.0 \mathrm{~mm}$ in

\footnotetext{
* Corresponding author: jhflorez@uniquindio.edu.co
} 
height and $\pm 1.0 \%$ in water content.

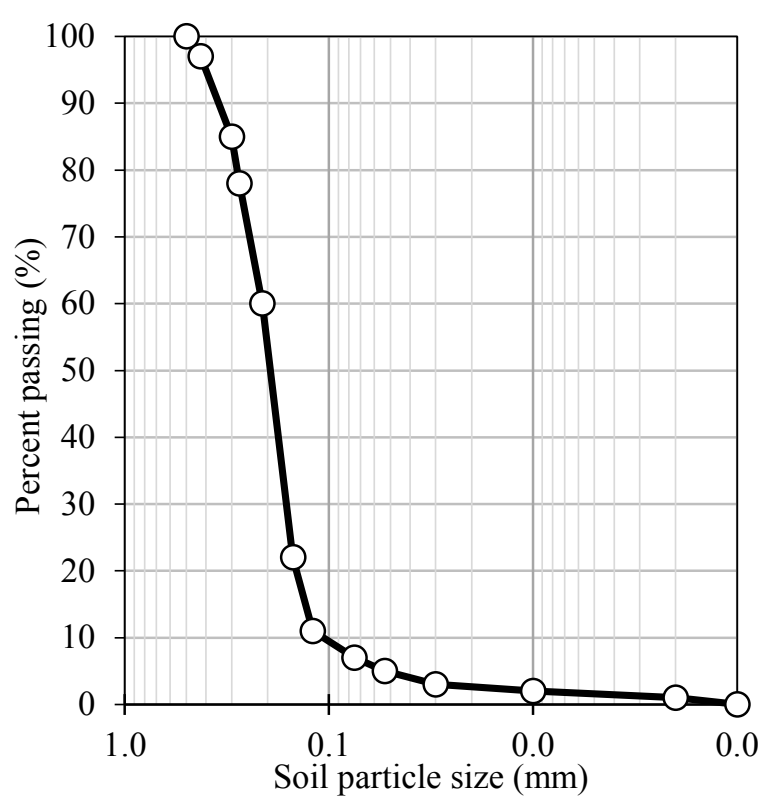

Fig 1. Grain size distribution of Osorio sand

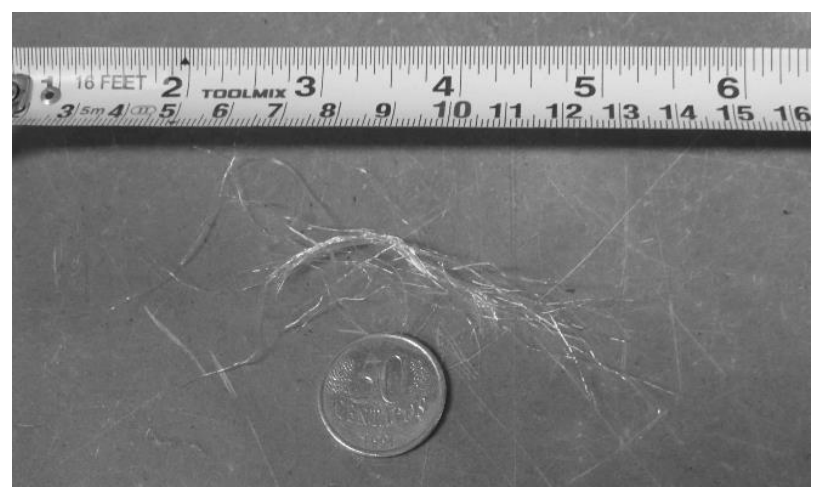

Fig 2. Polypropylene fibres used

\subsection{Triaxial tests}

Both drained and undrained tests were carried out following the same procedure until the consolidation process was finished. Firstly, carbon dioxide $\left(\mathrm{CO}_{2}\right)$ was flushed through the specimen during approximately 30 minutes. Then, distilled water was percolated until the volume collected was twice the volume of voids. During the saturation process by back pressuring, control was made through the Skempton "B" parameter, being accepted a minimum value of 0.95 .

The specimens were isotropically consolidated at effective confining pressure presented in Table 1. During the shearing stage, the strain rate was maintained in $1.8 \% /$ hour $(3.6 \mathrm{~mm} / \mathrm{h})$ for every test. Most tests were continued up to $15 \%$ axial strain. Axial and radial strains were monitored inside the triaxial cell through Hall-effect sensor-type local strain transducers. Outside the cell a standard displacement transducer was used. The volumetric strain was measured by an Imperial College type volume gauge.
Table 1. Summary of programme triaxial tests

\begin{tabular}{|c|c|c|c|}
\hline $\begin{array}{c}\text { Void } \\
\text { ratio (e) }\end{array}$ & $\begin{array}{c}\text { Fibre } \\
\text { content (\%) }\end{array}$ & $\begin{array}{c}\text { Condition } \\
\text { of test }\end{array}$ & $\begin{array}{c}\text { Confining } \\
\text { pressure (kPa) }\end{array}$ \\
\hline \multirow{4}{*}{0.75} & \multirow[t]{2}{*}{$x^{2}$} & $\mathrm{CD}^{(*)}$ & 50,100 e 200 \\
\hline & & $\mathrm{CU}$ & 20,100 e 200 \\
\hline & \multirow{2}{*}{0.5} & $\mathrm{CD}^{(*)}$ & 20,100 e 200 \\
\hline & & $\mathrm{CU}$ & 20,100 e 200 \\
\hline \multirow{4}{*}{0.63} & \multirow{2}{*}{0} & $\mathrm{CD}^{(*)}$ & 20,100 e 200 \\
\hline & & $\mathrm{CU}$ & 20,100 e 200 \\
\hline & \multirow{2}{*}{0.5} & $\mathrm{CD}^{(*)}$ & 20,100 e 200 \\
\hline & & $\mathrm{CU}$ & 20,100 e 200 \\
\hline
\end{tabular}

\section{Results and analysis}

The results of triaxial tests are presented in Fig.3. The parts (a) and (b) consist of the loose specimens and their results under drained and undrained conditions. Parts (c) and (d) correspond to dense, at the same test conditions than loose specimens.

For every situation, the first set of curves represent the behaviour of specimens until a maximum axial strain of $15 \%$. The second set of curves represents the same components, but up to a strain level of $2 \%$. The third set of curves represents the evolution of volumetric strain or the excess of pore pressure, depending on the type of test.

\subsection{Loose samples}

For drained tests, fibres addition generated two different situations: an unclear behaviour for strain levels lower than $1 \%$ (greater and smaller stiffness), and the transformation from strain-softening response into strainhardening response for the rest of tests, starting from the same level of strain.

A similar effect of fibres inclusion is observed in these specimens. Despite the level of effective confining pressure, the slope of the stress-strain curves is about the same. There was no significant effect of fibres on the volumetric strain response due to fibres addition, preserving not only the tendency of the curves, but also the maximum values.

For the undrained tests, it was very clear how fibres tend to increase the dilative tendency. In all cases, the compressive phase ends at lower strain levels and with lower values of positive pore pressure. The inversion of the sign of the excess of pore pressure brought an important increase in the effective stress for all reinforced specimens, resulting in significative gain of deviatoric stress for the same strain level, when compared with the no fibre condition. Similar behaviour was observed by [3] and [16].

\subsection{Dense samples}

Under drained conditions, a maximum strength peak was well defined for unreinforced samples, followed by a softening-strain behaviour, with tendency to stabilization for large strains. 

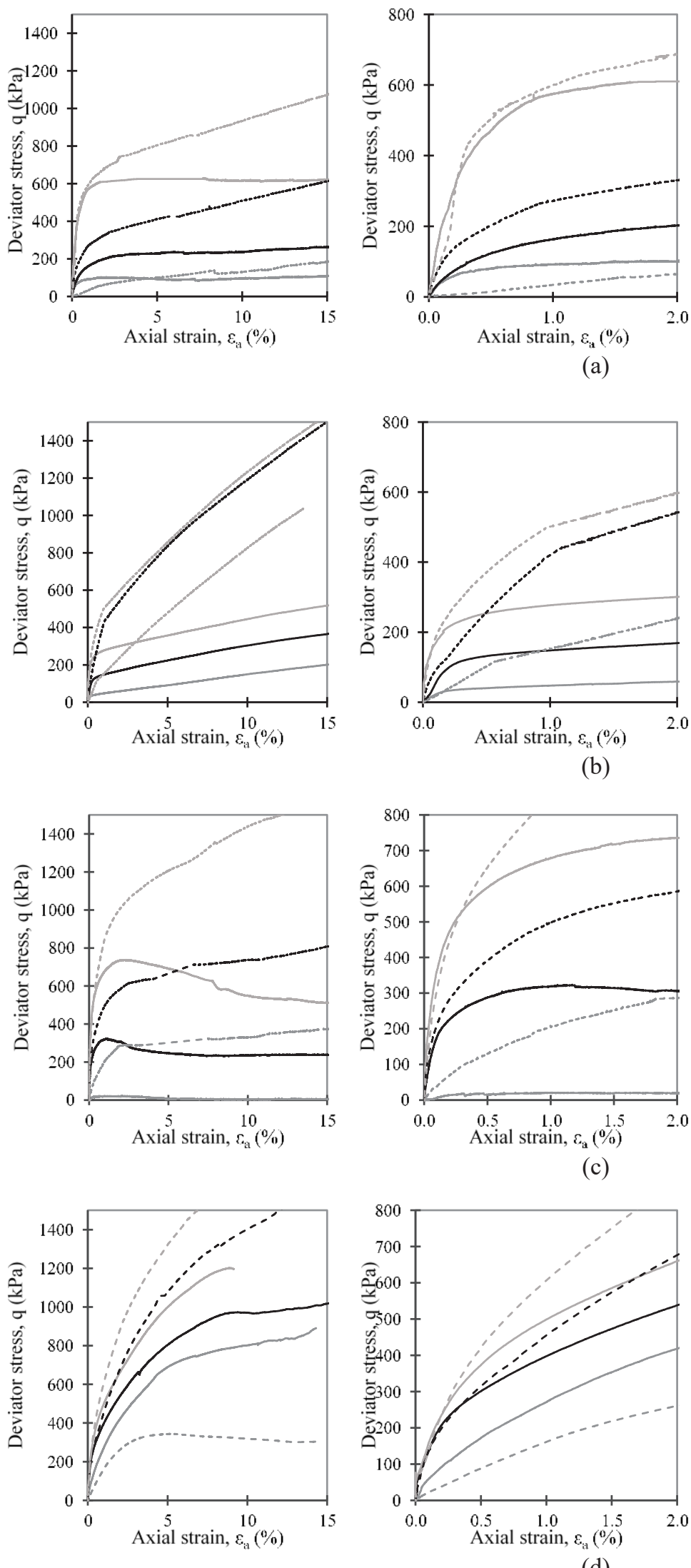

(d)

(a)

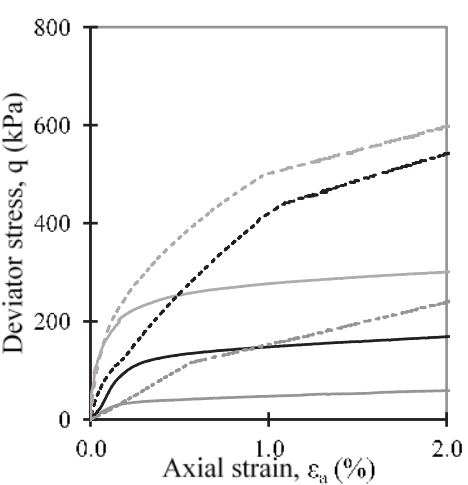

(b)

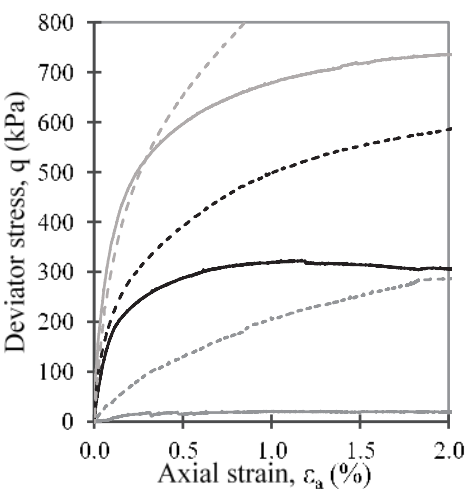

(c)
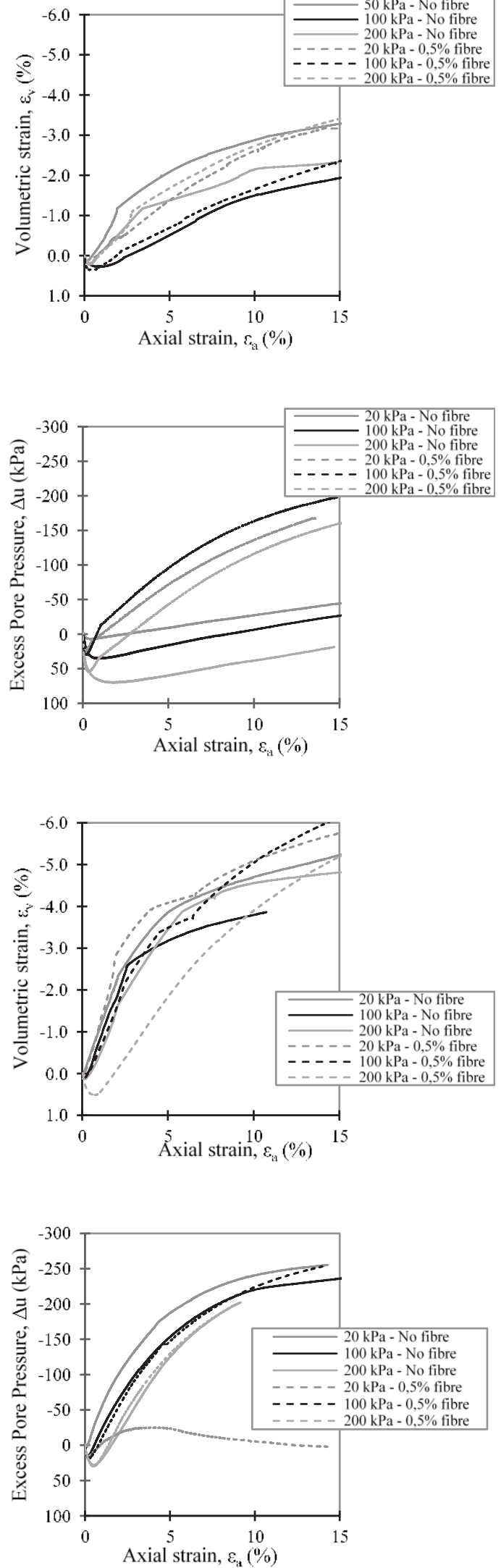

Fig 3. Drained and undrained response of unreinforced and reinforced sand at several confining pressure (a) Drained test at $\mathrm{e}_{0}=0.75$; (b) Undrained test at $\mathrm{e}_{0}=0.75$; (c) Drained test at $\mathrm{e}_{0}=0.63$ and, (d) Undrained test at $\mathrm{e}_{0}=0.63$.

The addition of fibres brought a strain-hardening behaviour for the composite, with stabilization at the end of tests, in accordance with the results presented by [16].
Nevertheless, for initial strains, the contribution of fibres was only observed from a certain value of strain, where the curves had a strong variation of their slopes. 
In this type of tests, it was not observed any significant difference of volumetric strains, with an "overlap" of the curves for most specimens.

For undrained tests, in this case, despite the increase in the slope of two of the three curves, the effect of the addition of the fibres was not so important when compared to the loose sand. This situation is confirmed by the excess of pore pressure curves, where there is no appreciable difference with one exception (effective confining pressure $20 \mathrm{kPa}-0.5 \%$ fibre). For the $20 \mathrm{kPa}$ test, possibly some experimental issue could have caused low pore pressure levels.

\subsection{Effect of fibres on the shear strength parameters}

For the determination of the shear strength parameters, the deviatoric stress of $10 \%$ axial strain was considered. In the cases where a peak was present, the respective value was adopted.

All obtained envelopes present a cohesion intercept of zero. The values of friction angle are presented in Table 2. The eight shear strengths envelopes obtained from triaxial tests are presented in Fig 4. The effect of the compaction is remarkable.

Table 2. Shear strength parameters for Osorio sand: no fibre and fibre reinforced conditions

\begin{tabular}{|c|c|c|c|}
\hline \multirow{2}{*}{$\begin{array}{c}\text { Void } \\
\text { ratio (e) }\end{array}$} & \multirow{2}{*}{$\begin{array}{c}\text { Fibre } \\
\text { content (\%) }\end{array}$} & \multicolumn{2}{|c|}{ Friction angle, $\boldsymbol{\phi}^{\prime}\left({ }^{\circ}\right)$} \\
\cline { 3 - 4 } 0.75 & 0 & Undrained & Drained \\
\cline { 2 - 4 } & 0.5 & 36.2 & $37.0^{(*)}$ \\
\hline \multirow{2}{*}{0.63} & 0 & 45.2 & $48.3^{(*)}$ \\
\cline { 2 - 4 } & 0.5 & 43.3 & $39.8^{(*)}$ \\
\hline \multicolumn{3}{|c|}{${ }^{(*)}$ Values previously obtained [16], [17] }
\end{tabular}

That effect is also very clear in drained test for the fibre reinforced sand. The friction angle increase was greater than $10^{\circ}$. For undrained tests, this effect was not so clear.

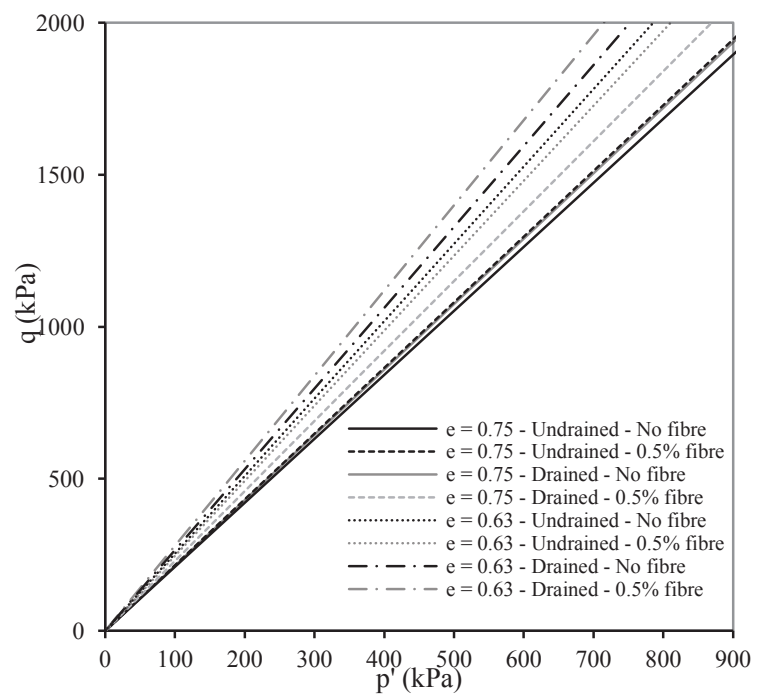

Fig 4. Shear strength envelopes for Osorio sand under drained and undrained conditions, no fibre and fibre reinforced, and $\mathrm{e}_{0}=0.75$ and 0.63 .

\section{Conclusions}

A series of triaxial tests was performed under consolidated-drained and consolidated-undrained conditions to study the effect of polypropylene fibres addition on the behaviour of a sand with two different conditions of compaction. The observations can be summarised as follows:

- The addition of fibres affects the behaviour of sand, mainly in post-peak conditions by modifying the strain-softening tendency into strain-hardening, until the completion of test.

- Fibre addition tends to reduce the contractive behaviour of sand, mostly in loose conditions.

- In most of cases, fibres increased the shearing strength parameters of sand. This situation can be better identified for drained tests.

The authors wish to express their gratitude to the Brazilian Ministry of Science and Technology/Brazilian Research Council (MCT/CNPq) for their financial support of the research group.

\section{References}

1. D. H. Gray, T. Al-Refeai, J. Geotech. Eng., 112, 8, 804-820 (1986)

2. B. K. Maheshwari, H. P. Singh, S. Saran, J. Geotechn and Geoenv Eng, 138, 7. 831-840 (2012)

3. W. Khebizi, N. Della, S. Denine, J. Canou, J. C. Dupla, Geomech. Geoengin., 1-11 (2018)

4. N. C. Consoli, A. Viana da Fonseca, R. C. Cruz, K. S. Heineck, J. Geotech. Geoenv. Eng., 135, 9, 13471353 (2009)

5. R. L. Michalowski, J. Čermák, J. Geotech. Geoenv. Eng., 129, 2, 125-136 (2003)

6. G. Ranjan, R. M. Vasan, H. D. Charan, Geotext. Geomembranes, 13, 8, 555-565 (1994)

7. D. Erdoğan, S. Altun, C.B.U. J. Sci., 1, 7-16 (2015)

8. D. H. Gray, H. Ohashi, J. Geotech. Eng., 109, 3, 335-353 (1983)

9. N. C. Consoli, M. A. Vendruscolo, A. Fonini, F. D. Rosa, Geotext. Geomembranes, 27, 3, 196-203 (2009)

10. N. C. Consoli, R. R. de Moraes, L. Festugato, R. R. de Moraes, L. Festugato, J. Mater. Civ. Eng., 25, 1568-1573 (2012)

11. A. Diambra, E. Ibraim, D. Muir Wood, A. R. Russell, Geotext. Geomembranes, 28, 3, 238-250 (2010)

12. E. Ibraim, A. Diambra, D. Muir Wood, A. R. Russell, Geotext. Geomembranes, 28, 4, 374-385 (2010)

13. J. H. Flórez-Gálvez, $\mathrm{PhD}$ Thesis (in portuguese) (2018)

14. P. Domone, J. Illston, Construction materials: their nature and behaviour, 4th ed. (2010)

15. R. S. Ladd, Geotech. Test. J., 1, 1, 16-23 (1978) 
16. N. C. Consoli, L. Festugato, K. S. Heineck, Geosynth. Int., 16, 1, 109-115 (2009)

17 L. Festugato, PhD Thesis (in portuguese) (2011) 